\title{
FLOW CYTOMETRIC ANALYSIS OF HUMAN ERYTHROCYTES: I. PROBED WITH LECTINS AND IMMUNOGLOBULINS
}

\author{
Karol A. Gutowski ${ }^{1}$, Jerry L. Hudson ${ }^{2}$ and David Aminoff ${ }^{1}$ \\ 'Institute of Gerontology, Department of Biological Chemistry, The University of Michigan, Ann Arbor, Michigan, \\ and ${ }^{2}$ Beckton-Dickinson, Immunocytometry System, San Jose, California 95131
}

\begin{abstract}
A recent review (Aminoff, 1988) summarized the evidence for and against our hypothesis for the role of glycophorin in the senescence and clearance of mammalian red blood cells (RBC) from circulation. This hypothesis postulates the loss of sialic acid from RBC surface in two forms: (a) as vesicles containing the sialoglycoprotein glycophorin, and (b) as free sialic acid residues from glycophorin molecules remaining on cell surface. In this report we demonstrate the applicability of flow cytometric procedures to explore, at the cellular level, time-dependent changes on RBC surface with change in cell size, and with in vivo age. The RBC are probed with fluorescein isothiocyanate (FITC) labelled lectins and goat anti-human-IgG and -IgM. The relative intensity of fluorescence is correlated to the change in RBC size as measured by forward lightscatter. Reactivity of RBC with FITC-labelled wheat germ agglutinin can be inhibited with either $0.2 \mathrm{M}$ $\mathrm{N}$-acetylglucosamine or by removal of sialic acid residues with neuraminidase. The properties of the smallest RBC correspond to those of the oldest RBC in their: (a) decreased reactivity with FITC-labelled lectins that recognize sialic acid residues, wheat germ and Limax flavus agglutinins, and (b) increased reactivity with FITC-labelled goat anti-humanIgG and -IgM. These results are compatible with our glycophorin hypothesis. Moreover, they suggest that the initial loss of sialic acid as glycophorin containing vesicles is gradual, while the subsequent step involving the loss of sialic acid residues is rapid and exposes multiple disaccharide galactose $\beta(1-3) \mathrm{N}$-acetylgalacosaminyl residues. These unmasked disaccharide sites are recognized by autoimmune $\operatorname{IgG}$, IgM, and lectin-like receptors on macrophages resulting in the clearance of senescent RBC from circulation.
\end{abstract}

Key Words: aging erythrocytes, autoimmune antibodies, cell size, flow cytometry, human, lectins, sialidase treatment

\section{INTRODUCTION}

THE EVIDENCE for and against our hypothesis for the involvement of glycophorin in the senescence and clearance of human RBC from circulation, at the end of their 120-day lifespan, recently was published (Aminoff, 1988). The essence of this hypothesis is the

Correspondence to: D. Aminoff, Institute of Gerontology, The University of Michigan, 300 North Ingalls Building, Ann Arbor, MI 48109-2007.

(Received 19 December 1989; Accepted 17 April 1990) 
time-dependent physiological desialylation of glycophorin on RBC surface with the exposure of $\mathrm{Gal} \beta(1,3) \mathrm{D}-\mathrm{N}$-Acetylgalactosamine (GalNAc) (galactose $\beta(1,3) \mathrm{N}$-acetylgalactosaminyl) residues. These are recognized by autoimmune $\operatorname{IgG}, \operatorname{IgM}$, and by the lectin-like receptors on macrophages of the reticuloendothelial system responsible for the clearance of the senescent RBC from circulation. Briefly, the evidence can be summarized as follows:

\begin{abstract}
a. Identification of more galactose oxidase and sialyl transferase (GOST) reactive sites on senescent as compared to young RBC separated on a density gradient (Aminoff et al., 1981). Detection of GOST sites can be attributed to the loss of covalently-bound sialic acid residues on RBC surface, resulting in exposure of the penultimate galactosyl residues in the senescent RBC. Exposed galactosyl residues are susceptible to both oxidation with galactose oxidase or to resialylation in vitro with liver sialyl transferases.

b. Isolation of the GOST sites from RBC by tryptic digestion (Thomas et al., 1981) followed by adsorption and elution from immobilized peanut lectin (PNA) (Henrich et al., 1983). Tryptic digestion releases glycopeptides from glycophorin A, but does not affect band 3, the anion exchanger (Steck, 1972). Immobilized PNA was used to isolate those glycopeptides that are free of sialic acid residues and that have the specific disaccharide structure recognized by PNA, namely, Gal $\beta(1,3)$ GalNAc. More of these disaccharidecontaining glycopeptides were isolated from senescent than from young RBC, and therefore were named senescence factor glycopeptides (SFGs) (Henrich et al., 1983).

c. The importance of these SFGs was further highlighted by their significant biological properties; namely, 1) the ability of spleen macrophages to recognize SFGs covalentlybound to fluorescent beads - with a loss of that recognition upon prior treatment of SFGs with $\beta$-galactosidase from bovine testes (Henrich et al., 1983), and 2) the ability of SFGs to inhibit the adhesion and phagocytosis of senescent RBC by autologous blood monocytes at nanomolar concentrations (Vaysse et al., 1986).
\end{abstract}

In the above studies, differential or density gradient centrifugation was used to separate the least dense (youngest) from the most dense (oldest) RBC (O'Connell et al., 1965; Cooper et al., 1980). Since density methods of separating young from senescent RBC have been severely criticized (Beutler, 1988), we sought alternative procedures to distinguish young from senescent RBC. The possibility of using flow cytometry with FITC-labelled lectins and immunoglobulins to demonstrate differences between the smallest (oldest) and largest (youngest) RBC was explored. Preliminary reports of these studies have already appeared (Aminoff et al., 1988; Gutowski et al., 1988).

\title{
MATERIALS AND METHODS
}

\section{Reagents}

Fluorescein isothiocyanate-labelled lectins were obtained as follows: wheat germ agglutinin (WGA) and peanut agglutinin (PNA) from Sigma Company (St. Louis, MO); Limax flavus agglutinin (LFA) from E.Y. Labs: Fluorescein isothiocyanate-labelled goat antihuman (GAH)-IgG and GAH-IgM were obtained from Kallestad Diagnostics (Austin, TX). Vibrio cholerae sialidase came from Calbiochem (San Diego, CA), and $\mathrm{N}$-acetylglucosamine from Sigma Co. (St. Louis, MO).

\section{Buffers}

Phosphate buffered saline (PBS) $\mathrm{pH} 7.4$ was $20 \mathrm{mM}$ phosphate and $0.85 \% \mathrm{NaCl},(280$ 
mOsmol). Isotonic TRIS buffered saline (ITBS) $\mathrm{pH} 7.4$ was $3 \mathrm{mM}$ TRIS, and $0.875 \%$ $\mathrm{NaCl}$, (275 mOsmol). Osmolalities were measured with a Wescor vapor pressure osmometer.

\section{Equipment}

RBC were analyzed on an Epics 541 flow cytometer (Coulter, Hialeah, FL) with a 4-watt argon laser (coherent) emitting at $488 \mathrm{~nm}$ with $600 \mathrm{~mW}$ output.

Bleeding and washing procedure. All blood for these studies was drawn by venipuncture in heparinized vacuum tubes or heparinized syringes from healthy 21 - to 23-year-old volunteers (three males and two females), and stored at $4^{\circ} \mathrm{C}$ for less than 12 hours. All donors signed an informed consent for scientific research statement. Immediately before use, 0.25 $\mathrm{ml}$ of the whole blood was centrifuged and the $\mathrm{RBC}$ washed three times with $1.25 \mathrm{ml}$ of PBS to remove plasma while leaving the buffycoat intact. Unless otherwise indicated, the washed cells were then resuspended in ITBS.

Flow cytometric counting. The flow cytometer was aligned according to Coulter's recommendations using standardized latex beads. Gates were set around the dense area of a forward lightscatter (FLS) vs. $90^{\circ}$ lightscatter histogram in order to exclude atypical cells. Fluorescein isothiocyanate (FITC) fluorescence at $530 \mathrm{~nm}$ was collected using the MDADS acquisition system (Coulter). For each sample, 10,000 cells were analyzed.

Osmolality. To determine effects of RBC cell shape on profiles obtained in the flow cytometer, RBC were diluted in saline solutions of different tonicity. The following concentrations were tested: $0.87 \% \mathrm{NaCl}$ (298 mOsmol), $0.78 \%(270), 0.70 \%$ (240), $0.61 \%$ (209), and $0.52 \%$ (179). At saline concentrations less than $0.52 \%$ the RBC lysed.

Treatment of RBC with FITC-labelled lectins. Fluorescein isothiocyanate-labelled lectins, $0.5 \mu \mathrm{g}$ - of FITC-WGA (2.3 moles FITC per mole protein), FITC-LFA, or FITC-PNA (2.5 moles FITC per mole protein) were added to $5 \times 10^{7} \mathrm{RBC}$ in $0.50 \mathrm{ml}$ of ITBS and incubated for $45 \mathrm{~min}$ at room temperature in the dark and a $2 \times 10^{7} \mathrm{RBC} / \mathrm{ml}$ suspension was used for flow cytometric analysis. These lectin concentrations gave optimal RBC labelling with minimal RBC agglutination. Washed RBC were used as controls for each experiment, and diluted to $2 \times 10^{7}$ cells per $\mathrm{ml}$ in ITBS for analysis in the flow cytometer.

Treatment of RBC with FITC-WGA in the presence of $N$-acetylglucosamine. $5 \times 10^{7}$ $\mathrm{RBC}$ were suspended in $0.2 \mathrm{M} \mathrm{N}$-acetylglucosamine in saline to adjust the tonicity. Cells then were treated with FITC-WGA as described above.

Treatment of $R B C$ with sialidase prior to addition of FITC-WGA. $1.25 \times 10^{8} \mathrm{RBC}$ were washed with ITBS, then incubated in ITBS containing $1 \mathrm{mM} \mathrm{CaCl}_{2}$ and 0.003 units of $V$. cholerae sialidase $\left(0.24\right.$ units $/ 10^{10} \mathrm{RBC}$ as previously specified, Aminoff et al., 1976) at $37^{\circ}$ for $30 \mathrm{~min}$. Following incubation, RBC were washed with ITBS and incubated with FITC-WGA as described above. 


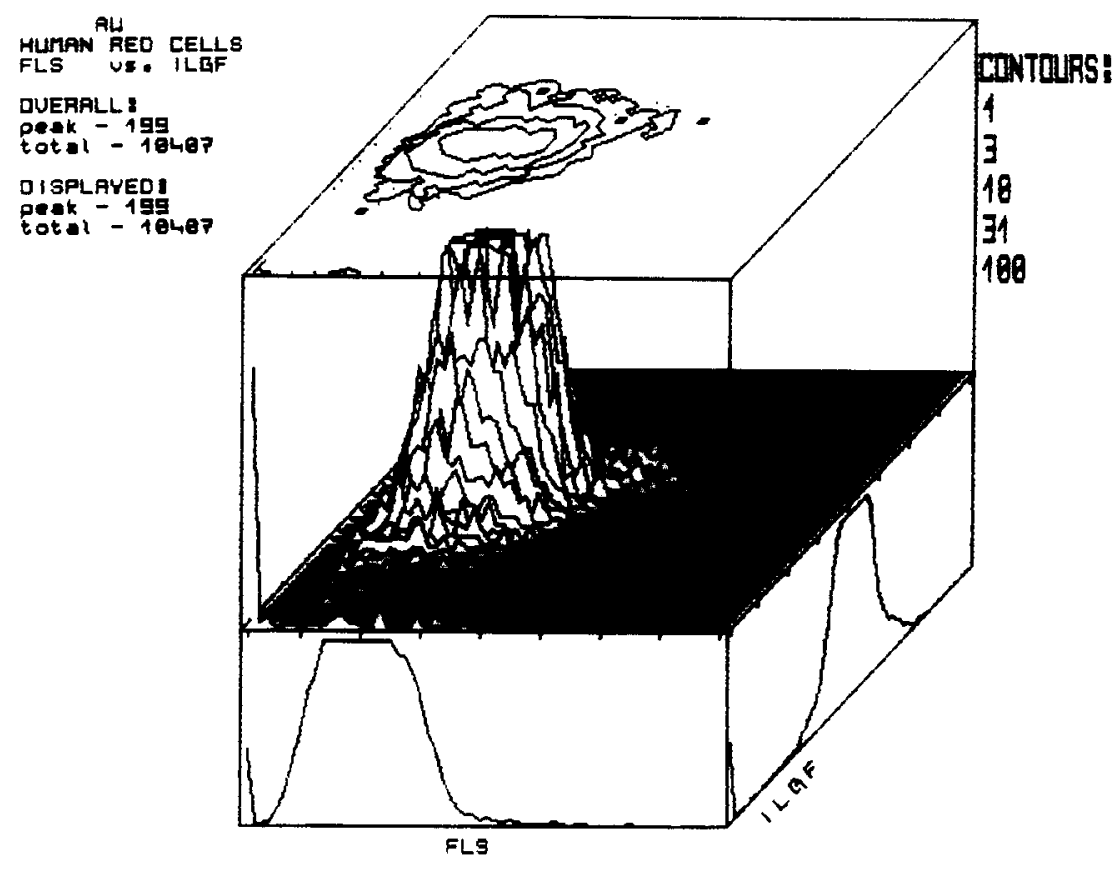

FIG. 1. Isometric three parameter visualization of the data for RBC labelled with FITC-WGA, under isotonic conditions relating cell size (FLS), intensity of $\log$ green fluorescence (ILGF), and number of cells. $5 \times 10^{7} \mathrm{RBC}$ were incubated with $0.5 \mu \mathrm{g}$ FITC-WGA; $2 \times 10^{7} \mathrm{RBC} / \mathrm{ml}$ were analyzed.

Treatment of RBC with FITC-GAH-IgG, and -IgM. $2.5 \times 10^{5} \mathrm{RBC}$ suspended in $0.1 \mathrm{ml}$ ITBS were incubated on ice for 1 hour with $2.0 \mu \mathrm{g}$ FITC-GAH-IgG, or FITC-GAH-IgM, before examination in the flow cytometer.

\section{RESULTS}

This study reports on changes in properties in cell surface with changes in cell size. It has been well established that RBC cell size decreases with in vivo age in circulation (Canaham, 1969). Cell size is the principal component of the forward lightscatter (FLS) signal. The relative intensity of fluorescence is an indicator of changes on the cell surface monitored with the appropriate FITC-labelled probe: lectin or immunoglobulin. Figure 1 illustrates a typical three parameter histogram of lightscatter, $\log$ green fluorescence, and cell numbers for RBC probed with FITC-WGA. The scattergram with contour lines is the two-dimensional presentation of the same data. Both representations give a general overview of the flow cytometric data. However, like Dockter and Morrison (1986), we found the mean channel of fluorescence vs. lightscatter channel plot more informative.

\section{Distribution of red blood cells according to cell size and effect of tonicity}

Simultaneous with the decrease in cell size with in vivo age of RBC in circulation, there is a change in shape - from a young biconcave ellipsoid cell to that of an almost symmet- 


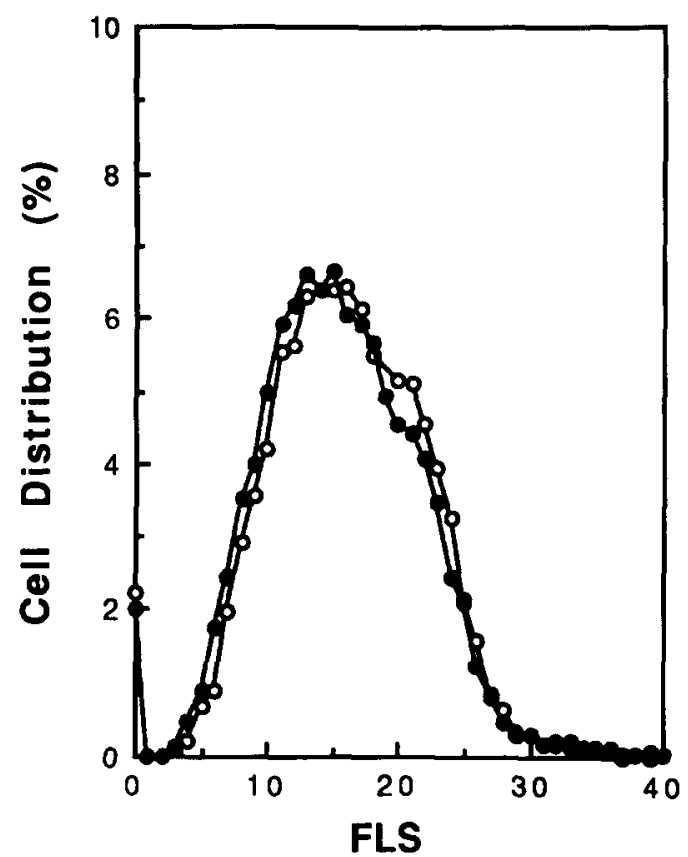

FIG. 2. Effect of FITC-WGA on RBC cell distribution. RBC were incubated with (O) or without (O) FITC-WGA as in Figure 1.

rical sphere for the oldest (smallest) population of RBC. It therefore was of interest to determine the effect of tonicity, more specifically hypotonicity, on the sphericity of the cell, as detected by the flow cytometer. Previous investigators have made a great issue of this point (Kim et al., 1983). Under isotonic conditions, we obtained a monomodal Gaussian distribution curve for RBC size (Fig. 2). There was little if any significant change in the cell size distribution curve at tonicities of $298 \mathrm{mOsmol}$ (isotonic) Figure 2, and $240 \mathrm{mOsmol}$ (not shown). However, at $170 \mathrm{mOsmol}$, the profile was distorted and the debris from the lysed cells appeared as smaller particles. Therefore, since isotonic conditions were adequate, we felt it unnecessary to change the tonicity in subsequent studies.

\section{Effect of addition of FITC-WGA on the RBC cell size distribution}

Wheat germ agglutinin is a very strong agglutinating agent. However, under the optimal conditions used, it imparted a strong fluorescence to the cells without affecting cell size distribution, indicating the absence of dimers or more complex aggregates of the RBC (Figs. 1 and 2).

\section{Reproducibility of data with FITC-WGA}

Figure 3 (A) illustrates the cell size distribution for RBC from five individuals, each determined in triplicate in the presence of the FITC-WGA. Figure 3 (B) shows the mean ILGF for each of two FLS channels. It is readily apparent that the mean fluorescence channel was 

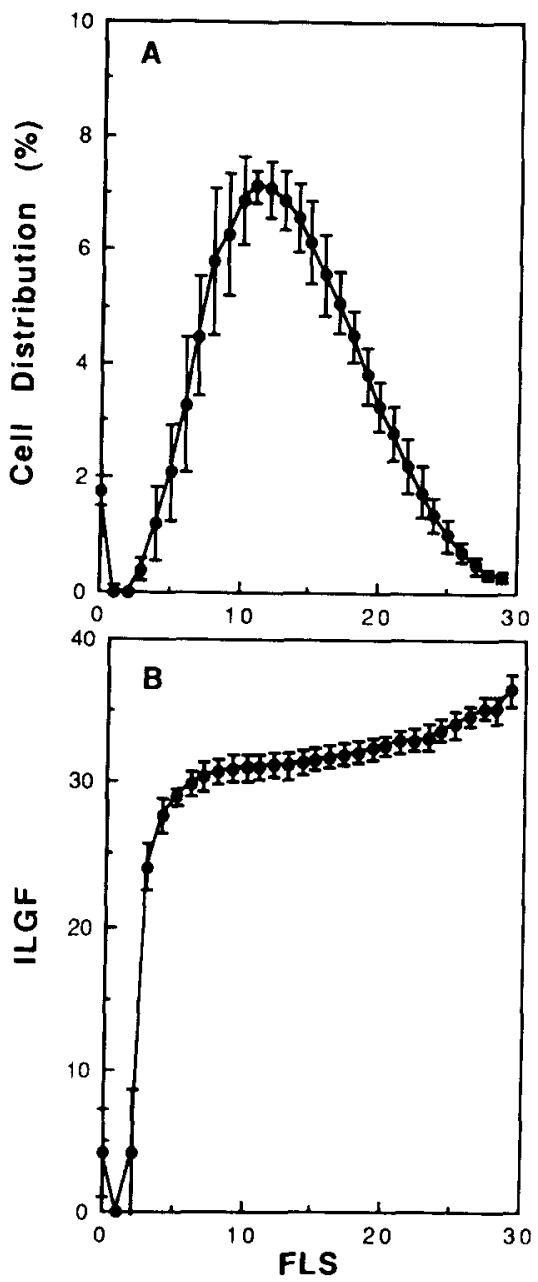

FIG. 3. Reproducibility of data with FITC-WGA. RBC from five individuals were incubated in triplicate with FITC-WGA as in Figure 1 . A \% cell distribution (mean $\pm S D$ ) vs. FLS; B ILGF (mean $\pm S D$ ) vs. FLS.

remarkably constant over the whole spectrum of cell sizes; however, it dropped precipitously with the smallest RBC. For 10,000 events monitored, the statistics are reliable for most cells in the middle of the spectrum. At the two extremes of the spectrum, however, the smallest and largest RBC corresponding to $0.5 \%$ of the total populations of cells, only 50 cells would be counted and error would be greater. It is apparent, nevertheless, that the smallest cells showed little, if any, reactivity with FITC-WGA, implicating the absence of significant numbers of sialic acid residues on the surface of these cells.

\section{Reaction of RBC with different FITC-labelled lectins}

Both WGA and LFA react with sialic acid residues (Bhavanadan et al., 1979) on cell surfaces, and both give essentially similar patterns of fluorescence (Fig. 4). LFA is more 


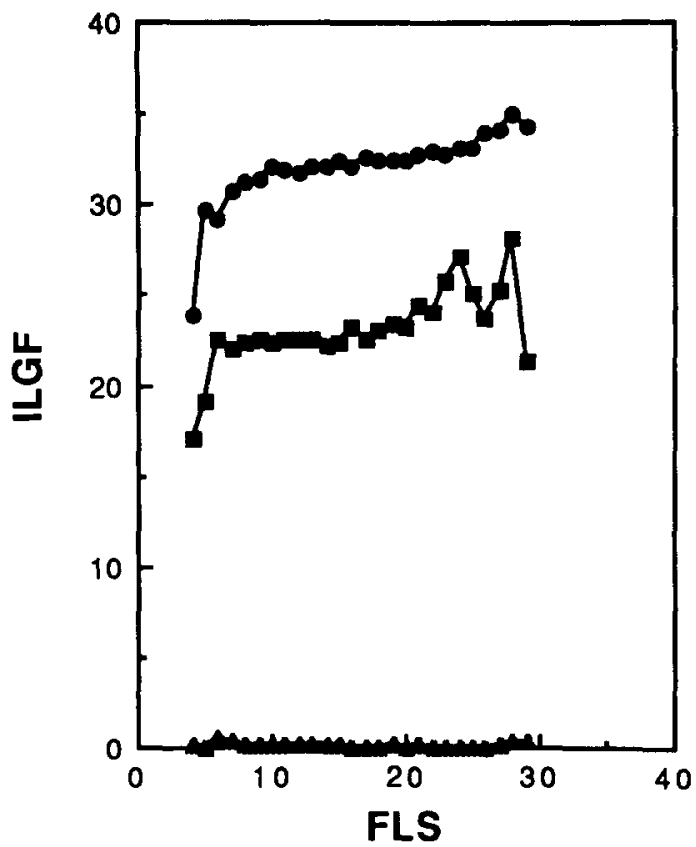

FIG. 4. Reaction of RBC with FITC-lectins. $5 \times 10^{7} \mathrm{RBC}$ were incubated with $0.5 \mu \mathrm{g}$ of FITCWGA (O), -LFA ( $\boldsymbol{\square})$, or -PNA (A); $2 \times 10^{7} \mathrm{RBC} / \mathrm{ml}$ were analyzed.

specific for sialic acid residues (Miller et al., 1982), since WGA will react also with polymers of $\mathrm{N}$-acetylglucosamine and erythroglycans (Bhavanadan et al., 1979). Nonetheless, most of the studies were undertaken with WGA because of its ready availability (the LFA is seasonal and was not available to us when required in quantity). Additionally, as has been previously shown by others, WGA reacts with glycophorin of RBC in preference to erythroglycan (Ivatt et al., 1986). The RBC showed no reactivity with FITC-PNA (Fig. 4).

\section{Specificity of FITC-WGA for sialic acid residues on RBC surface}

The specificity of WGA for RBC sialic acid residues can be verified in two ways; either by inhibition with a competitor of sialic acid residues, or by their removal by treatment with sialidase. The effects of both these treatments on reactivity with FITC-WGA are demonstrated in Figure 5. It should be emphasized that inhibition with $\mathrm{N}$-acetyl-glucosamine (GlcNAc) and sialidase treatment showed interesting differences. The extent of inhibition by GlcNAc appeared to be the same irrespective of cell size. On the other hand, it would appear that there was differential desialylation of RBC depending on cell size. The smallest $\mathrm{RBC}$ appeared to be more susceptible to desialylation than the larger RBC.

\section{Reaction of human RBC with goat-anti-human -IgG, -IgM}

It is apparent from the results obtained, Figure 6, that, while there appeared to be low reactivity with both GAH-IgG and -IGM, the smallest cells showed the greatest reactivity. 


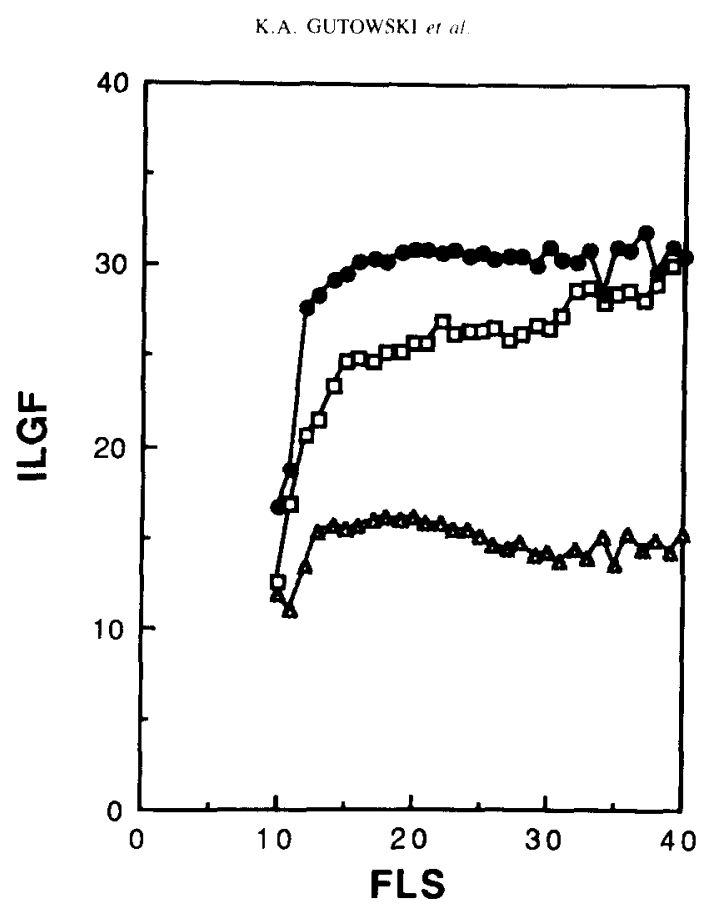

FIG. 5. Reaction of human washed RBC with FITC-WGA in the presence of N-acetylglucosamine, or with prior sialidase treatment. $5 \times 10^{7} \mathrm{RBC}$ were incubated with $0.5 \mu \mathrm{g}$ FITCWGA (-). $1.25 \times 10^{8} \mathrm{RBC}$ were incubated in ITBS containing $1 \mathrm{mM} \mathrm{CaCl}_{2}$ and 0.003 units neuraminidase at $37^{\circ} \mathrm{C}$. Following parital desialylation RBC were washed with ITBS and $5 \times$ $10^{7} \mathrm{RBC}$ were incubated with FITC-WGA ( $\square$ ). $5 \times 10^{7} \mathrm{RBC}$ were suspended in $0.2 \mathrm{M} \mathrm{N}$-acetylglucosamine and then incubated with FITC-WGA $(\triangle)$. For all conditions $2 \times 10^{7} \mathrm{RBC} / \mathrm{ml}$ were analyzed.

\section{DISCUSSION}

We are interested in the cellular and molecular basis of aging. The red cell appears to be a good model to study. Previous investigations have indicated that in vivo aging of RBC can, as a first approximation, be correlated with increase in density or decrease in cell size. The increase in density approach to isolate senescent RBC has had extensive use with decreasing confidence in the data obtained. We thought it desirable to attempt an alternative approach utilizing the change in cell size to explore how far it could be used as a parameter to designate cell age.

The enormous potential of flow cytometric procedures (FCP) has been demonstrated in immunology and oncology (Shapiro, 1985; Melamed et al., 1979). However, application of FCP to RBC was neglected for many years because of the nonspherical shape of RBC. Early applications restricted the analysis to the counting of fluorescently labelled cells in the presence of unlabelled cells, where cell shape could be ignored, that is, detection of fetal RBC in maternal circulation (Greaves, 1975; Horan, 1981; Medearis et al., 1984), detection of monoblasts in the blood of thalassemic patients (Rachmilewitz et al., 1978), separation of malaria-infected from noninfected RBC (Howard et al., 1979; Brown et al., 1981), or detection of reticulocytes in blood (Tanke et al., 1980; 1983; Jacobberger et al., 1984).

With the demonstration that it was possible to detect differences in cell size of glutaraldehyde-treated RBC after isovolumetric-sphering (Kim et al., 1983), it became evident that 


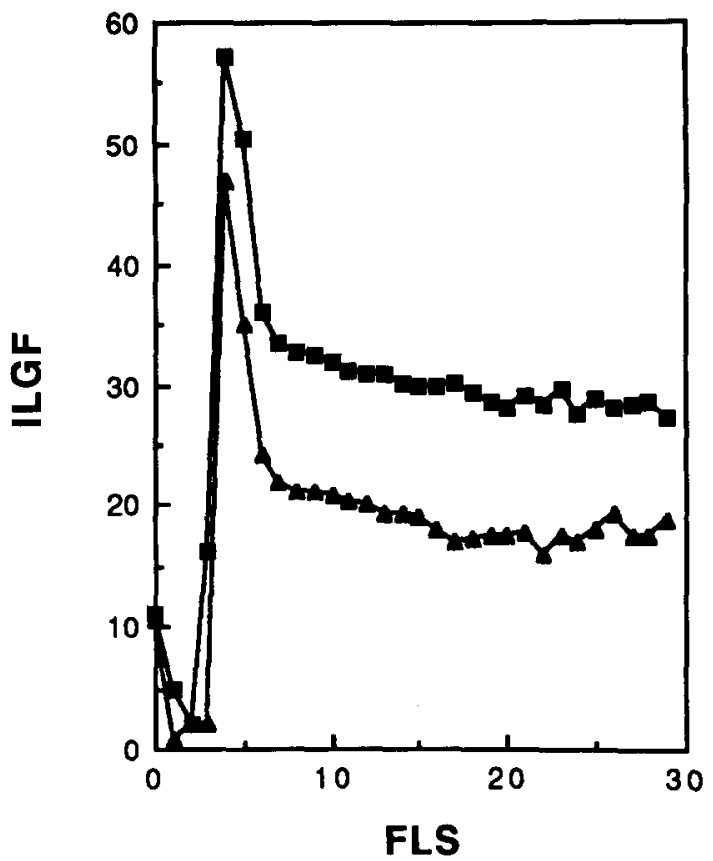

FIg. 6. Reaction of RBC with FITC-GAH-IgG, and FITC-GAH-IgM. $2.5 \times 10^{5}$ RBC in $0.1 \mathrm{ml}$ were incubated on ice for one hour with $2 \mu \mathrm{g}$ FITC-GAH-IgG $(\mathbf{O})$, or FITC-GAH-IgM (A).

FCP could be applied to detect differences between young and senescent RBC taking advantage of differences in their cell size.

Some pioneers did attempt to correlate changes in cell surface parameters with change in cell size (Jennings et al., 1985; Dockter et al., 1986). Fluorescently labelled lectins also had been used to detect specific sugars on lymphocytes (Stein et al., 1973; Wiig et al., 1973; Kraemer et al., 1973; Steinkamp et al., 1974). Since lectins can bind to RBC at low concentrations without causing agglutination (Reisner et al., 1976), it became evident that FCP could be applied to RBC.

From the results of this study it is apparent that, irrespective of this change in size and shape as they age in vivo, RBC can be monitored readily by flow cytometry under isotonic conditions. This makes it possible to follow changes in structural and functional properties of RBC as a function of size as reflected by FLS.

The approach we found most useful was to plot the mean channel fluorescence vs. cell size, as previously used (Jennings et al., 1985; Dockter et al., 1986). That approach demonstrated the difference between the reactivity of $\mathrm{RBC}$ with fluorescent antibody that detected acetylcholinesterase, and eosin-5-maleimide that detected band 3 (the anion exchanger on $\mathrm{RBC}$ ), respectively. It is interesting to note that in contrast to band 3 , which remained constant throughout the life span of $\mathrm{RBC}$ in circulation irrespective of cell size (Jennings et al., 1985), in our studies sialic acid-containing receptors showed a decrease in the smallest $\mathrm{RBC}$ when probed with WGA, thus making them potentially suitable receptors for monitoring $\mathrm{RBC}$ senescence. This is especially so, since these smallest cells showed a greater fluorescence when probed for the presence of autoimmune antibodies on their cell surface.

Under optimal conditions, it is possible to follow changes in both cell surface sialic acid 
on $\mathrm{RBC}$ and reactivity with goat-anti-human-IgG, -IgM. It would appear that most of the RBC, irrespective of cell size, are saturated with FITC-labelled lectins that detect sialic acid residues (Lovrien et al., 1980). In contrast, the smallest $\mathrm{RBC}$ show minimal reactivity with FITC-WGA and maximal reactivity with autoimmune IgG and IgM as detected with the FITC-labelled goat-anti-human-IgG, and -IgM. These results are compatible with our hypothesis for the progressive desialylation of covalently-bound sialic acid residues on glycophorin molecules of RBC surface (Aminoff, 1988). Most of the RBC, with their sialic acid content unchanged on the cell surface, would not be expected to react with FITC-PNA (Fig. 4). The nonreactivity of the smallest RBC with PNA is attributable to the presence of the autoimmune IgG and IgM [anti- $T$, the Thomsen-Friedenrich antibody present in all human sera (Propkop et al., 1969)] on the RBC cell surface, presumably with an anti- $\beta$-galactosyl specificity.

It is interesting to note that under conditions of partial desialylation, the smallest RBC are the most rapidly desialylated. This is consistent with the observed apparent precipitous decrease in reactivity of the smallest RBC with FITC-WGA. Thus, it would appear that the sequence of events involves first the decrease in cell size - due to loss of cell membrane as vesicles (Weed et al., 1966) - and only when the cell is small and spherical does it rapidly lose its sialic acid residues. Simultaneous with this desialylation, the cells acquire autoimmune $\operatorname{IgG}$ and $\operatorname{IgM}$ from the serum.

Thus, it would appear that the smallest $\mathrm{RBC}$ could correspond to the oldest $\mathrm{RBC}$ by the criteria previously established, namely a decreased sialic acid, and increased amount of autoimmune IgG and IgM (Aminoff, 1988). Compliance with expectations, however, is not proof. Unfortunately, the studies with the Coulter Epics were curtailed due to circumstances beyond our control but definitive evidence is forthcoming using Becton-Dickinson FACScan flow cytometer. Therefore, the applicability of using either flow cytometer to study RBC can be compared.

\section{CONCLUSIONS}

1. RBC surface changes as a function of cell size can be monitored by flow cytometry of RBC directly and labelled with suitable fluorescent probes.

2. The properties of the smallest $\mathrm{RBC}$ correspond to the properties of oldest RBC with respect to:

(a) their nonreactivity with sialic acid-detecting lectins, and

(b) their increased reactivity with autoimmune IgG and IgM.

These observations are compatible with our hypothesis that glycophorin is the putative molecule on RBC cell surface that shows time-dependent changes, and that it could be responsible for the ultimate clearance of senescent RBC from circulation.

Acknowledgments - The authors wish to thank Diane E. Brede for her efficient technical assistance in the use of the Coulter Epics 541 flow cytometer, and Stephen Kelley for his software program which facilitated the conversion of the raw data to provide the mean channel of fluorescence vs. FLS curves used extensively in these studies. Stephen Kelley is currently at the cytometry laboratories of Purdue University Cancer Center. We gratefully appreciate the many helpful discussions we have had with Drs. Curt Hanson, Robert Todd, and Geneva Omann, and secretarial assistance of Ms. Fran A. Gruda. This research was supported by the National Institute of Health grant \#AG 08018. 


\section{REFERENCES}

AMINOFF, D., BELL, W.C., FULTON, I., and INGEBRIGTSEN, N. Effect of sialidase on the viability of erythrocytes in circulation. Amer. J. Hemat. 1, 419-432, 1976.

AMINOFF, D., GHALAMBOR, M.A., and HENRICH, C.J. GOST, galactose oxidase and sialyl transferase substrate and receptor sites in erythrocyte senescence: In: Erythrocyte Membranes 2: Recent Clinical and Experimental Advances, Kruckeberg, W.C., Eaton J.W., Brewer, G.J. (Editors), pp. 269-278, Alan R. Liss, Inc., New York, 1981.

AMINOFF, D. The role of sialoglycoconjugates in the aging and sequestration of red cells from circulation. Blood Cells 14, 229-257, 1988.

AMINOFF, D., GUTOWSKI, K.A., BREDE, D.E., and HUDSON, J.L. Flow cytometric analysis of human erythrocytes probed wh FTC-labelled lectins. In: Proceedings of Japanese-German Symposium on Sialic Acids, Schauer, R., and Yothakawa, T. (Eds.), pp. 224-225. Kieler Verlag Wissenschaft Bildung, Kiel, 1988.

BEUTLER, E. The relationship of red cell enzymes to red cell life span. Blood Cells 14, 69-75, 1988.

BHAVANADAN, V.P. and KATLIC, A.W. The interaction of wheat germ agglutinin with sialoglycoproteins. The role of sialic acid. J. Biol. Chem. 254, 4000-4008, 1979.

BROWN, G.V., BATTYE, F.L., and HOWARD, R.J. Separation of stages of Plasmodium falciparum infected cells by means of a fluorescence-activated cell sorter. Biol. Abstr. 71, 7922, 1981.

CANHAM, P.B. Differences in geometry of young and old human erythrocytes explained by a filtration mechanism. Circ. Res. 25, 39-45, 1969.

COOPER, A.J. and PERRY, S. The applicability of freeze-thaw percoll gradients to whole cell isopycnic fractionations: Preliminary results. J. Immunol. Meth. 37, 353-361, 1980.

DOCKTER, M.E. and MORRISON, M. Paroxysmal noctumal hemoglobinuria erythrocytes are of two distinct types: Positive or negative for acetylcholinerase. Blood 67, 540-543, 1986.

GREAVES, M.F. Clinical applications of cell surface markers. Progress in Hematol. 9, 255-303, 1975.

GUTOWSKI, K.A., BREDE, D.E., HUDSON, J.L., and AMINOFF, D. Flow cytometric analysis of human erythrocytes probed with FITC-labelled lectins and immunoglobulins. Glycoconjugate J. 5, 355, 1988.

HENRICH, C.J. and AMINOFF, D. Isolation and characterization of a glycopeptide from human senescent erythrocytes. Carbohydr. Res. 120, 55-66, 1983.

HORAN, P.K. Hematology: Single-cell analysis enters the space age. Diagnostic Medicine, October, 63-85, 1981.

HOWARD, R.J. and RODWELL, B.J. Babesia rodhaini, Babesia bovis, and Babesia bigemina. Analysis and sorting of red cells from infected mouse or calf blood by flow fluorometry using 33258 Hoechst. Biol. Abst. 69, $5637,1979$.

IVATT, R.J., HARNETT, P.B., and REEDER, J.W. Isolated erythroglycans have a high-affinity interaction with wheat germ agglutinin, but are poorly accessible in situ. Biochim. Biophys. Acta 881, 124-134, 1986.

JACOBBERGER, J.W., HORAN, P.K., and HARE, J.D. Flow cytometric analysis of blood cells stained with the cyanine dye $\mathrm{DiOC}_{1}[3]$ : Reticulocyte quantification. Cytometry 5, 589-600, 1984.

JENNINGS, L.K., BROWN, L.K., and DOCKTER, M.E. Quantitation of protein 3 content of circulating erythrocytes at the single cell level. Blood 65, 1256-1262, 1985.

KIM, Y.R. and ORNSTEIN, L. Isovolumetric sphering of erythrocytes for more accurate and precise cell volume measurement by flow cytometry. Cytometry 3, 419-427, 1983.

KRAEMER, P.M., TOBEY, R.A., and VAN DILLA, M.A. Flow microfluorometric studies of lectin binding to mammalian cells. I. General Features. J. Cell Physiol. 81, 305-314, 1973.

LOVRIEN, R.E. and ANDERSON, R.A. Stoichiometry of wheat germ agglutinin as a morphology controlling agent and as a morphology protective agent for the erythrocyte. J. Cell Biol. 85, 534-548, 1980.

MEDEARIS, A.L., HENSLEIGH, P.A., PARKS, D.R., and HERZENBERG, L.A. Detection of fetal erythrocytes in matemal blood post partum with the fluorescence-activated cell sorter. Am. J. Obstet. Gynecol. 148, 290$295,1984$.

MELAMED, M.R., MULLANEY, P.F., and MENDELSOHN, M.L. (Ed.). Flow Cytometry and Sorting. John Wiley \& Sons, New York, 1979.

MILLER, R.L., COLLAWN, J.F., and FISH, W.W. Purification and macro-molecular properties of a sialic acidspecific lectin from the slug Limax flavus. J. Biol. Chem. 257, 7574-7580, 1982.

NAGATA, Y. and BURGER, M.M. Wheat germ agglutinin. Isolation and crystallization. J. Biol. Chem. 246, 2248-2250, 1972.

O'CONNELL, D.J., CARUSO, C.J., and SASS, M.D. Separation of erythrocytes of different ages. Clin. Chem. 11, 771-781, 1965. 
PROKOP, O. and UHLENBRUCK, G. (Eds.). Human Blood and Serum Groups. Translated by J.L. Raven, Ind. ed. pp. 103-110, Maclaren \& Sons, Ltd, , 1969.

RACHMILEWITZ, E.A. and THORELL, B. Characterization of the normoblast population in $\beta$-thalassemic blood by rapid-flow cytofluorometry. Scand. J. Haematol. 20, 440-446, 1978.

REISNER, Y., LIS, H., and SHARON, N. On the importance of the binding of lectins to cell surface receptors at low lectin concentrations. Expt. Cell Res. 97, 445-448, 1976.

SHAPIRO, H.M. Practical Flow Cytometry. Alan R. Liss, Inc., New York, 1985.

STECK, T.L. The organization of proteins in human erythrocyte membranes. In: Membrane Research, Fox, C.F. (Ed.), pp. 71-93, Academic Press, New York, 1972.

STEIN, G., FLAD, H.D., PABST, R., and TREPEL, F. Separation of human lymphocytes by free-flow electrophoresis. Biomedicine. 19, 388-391, 1973.

STEINKAMP, J.A. and KRAEMER, P.M. Flow microfluorometric studies of lectin binding to mammalian cells. II Estimation of the surface density of receptor sites by multiparameter analysis. I. Cell Physiol. 84. 197-204. 1974.

TANKE, H.J., NIEUWENHUIS, I.A.B., KOPER, G.J.M., et al. Flow cytometry of human reticulocytes based on RNA fluorescence. Cytometry. 1, 313-320, 1980.

TANKE, H.J., ROTHBARTH, P.H., VOSSEN, J.M.J.J., et al. Flow cytometry of reticulocytes applied to clinical hematology. Blood 61, 1091-1097, 1983.

THOMAS, D.B. and WINZLER. R.J. Structural studies on human erythrocyte glycoproteins. Alkali-Labile oligosaccharides. J. Biol. Chem. 244, 5943-5946, 1969.

VAYSSE, J., GATTEGNO, L., BLADIER, D., and AMINOFF, D. Adhesion and erythrophagocytosis of human senescent erythrocytes by autologous monocytes and their inhibition by $\beta$-galactosyl derivatives. Proc. Natl. Acad. Sci. U.S.A. 83, 1339-1343, 1986.

WEED, R.I. and REED, C.F. Membrane alterations leading to red cell destruction. Amer. J. Med. 41, 681-698, 1966.

WIIG, J.N. and THUNOLD, S. Electrophoresis of lymphoid cells. Characterization of human B and $T$ cells in peripheral lymphoid tissues. Clin. Expt. Immunol. 15, 497-506, 1973. 